https://doi.org/10.32689/2618-0065-2020-3(5)-204-215

Рєзніков Валерій Володимирович, кандидат економічних наук, доцент, докторант навчально-науково-виробничого центру, Національний університет цивільного захисту України, 61024, м. Харків, вул. Лермонтовська, 28, тел. (050) 632-16-93, e-mail: osvita00@gmail.com, https//orcid.org/0000-0002-3579-3114

\title{
ШЛЯХИ ТРАНСФОРМАЦІЇ ДЕРЖАВНОЇ ПОЛІТИКИ У СФЕРІ ЄВРОПЕЙСЬКОЇ ІНТЕГРАЦЇ̈ УКРАЇНИ В УМОВАХ ГЛОБАЛЬНИХ ВИКЛИКІВ
}

Анотація. Орієнтиром розвитку України в сучасних умовах є країничлени Європейського Союзу, які мають ефективнішу систему державного управління, де громадяни є більш захищеними у своїх правах, мають вищий рівень життя та впевненість у майбутньому. Шлях до цього орієнтиру пролягає для України через процес європейської інтеграції - внутрішні реформи, викорінення корупції, адаптацію до європейських стандартів, економічну інтеграцію та політичну асоціацію з СС. Тому актуальними $\epsilon$ питання формування та реалізації нової державної політики у сфері європейської інтеграції, яка відповідає існуючим викликам сьогодення.

Деяке зниження показника підтримки євроінтеграції серед населення України в останні роки може свідчити про зниження ефективності та результативності державної політики у сфері європейської інтеграції, яка потребує трансформації у відповідних напрямах іiі реалізації в сучасних умовах глобальних викликів для України.

Результативність державної політики у сфері європейської інтеграції України значною мірою залежить від вчасного виконання нашою державою Угоди про асоціацію з СС, яку в частині секторальної інтеграції Україна має завершити не пізніше кінця 2023 р., а загалом усі положення Угоди, мають бути виконані не пізніше 31 грудня 2025 р.

Трансформація державно політики у сфері європейської інтеграції передбачає відповідну зміну вектору вирішення політичних, правових, економічних, соціальних, екологічних, гуманітарних питань 3 урахуванням змін у процедурі вступу для країн-претендентів та у відповідності 3 існуючими європейськими стандартами. А можливість членства України в Європейському Союзі має стати стратегічним напрямом модернізаційних перетворень в державі, спрямованих на побудову демократичної соціальної держави з міцною економікою та розвинутим громадянським суспільством.

Ключові слова: європейська інтеграція, державна політика у сфері європейської інтеграції, Угода про асоціацію між Україною та Європейським Союзом. 
Ryeznikov Valeriy Volodymyrovych, $\mathrm{PhD}$ in Economic Sciences, associate professor, doctoral student of educational-scientific-production center, National University of Civil Protection of Ukraine, 61024, Kharkiv, Str. Lermontovs'ka, 28, tel.: (050) 632-16-93, e-mail: osvita00@gmail.com, https//orcid.org/0000-0002-3579-3114

\title{
WAYS OF STATE POLICY TRANSFORMATION IN THE SPHERE OF EUROPEAN INTEGRATION OF UKRAINE IN CONDITIONS OF GLOBAL CHALLENGES
}

\begin{abstract}
The benchmark for Ukraine's development in modern conditions is the member states of the European Union, which have more effective system of public administration where citizens are more protected in their rights, have a higher standard of living and confidence in the future. The path to this landmark lies for Ukraine through the process of European integration - internal reforms, eradication of corruption, adaptation to European standards, economic integration and political association with the EU. Therefore, the issues of formation and implementation of a new state policy in the sphere of European integration, which meets the existing challenges of today, are relevant.

Some decrease in the rate of support for European integration among the population of Ukraine may indicate a decrease in the effectiveness and efficiency of state policy in the sphere of European integration in recent years which requires modernization in the relevant areas of its implementation in today's global challenges for Ukraine.

The effectiveness of Ukraine's state policy in the sphere of European integration largely depends on the timely implementation by our country of the Association Agreement with the EU which in terms of sectoral integration Ukraine must complete no later than the end of 2023 and in general all provisions of the Agreement to be performed no later than December 312025.

In modern conditions the state policy in the sphere of European integration of Ukraine must undergo certain transformation which involves a corresponding change in the vector of political, legal, economic, social, environmental, humanitarian issues taking into account changes in the accession procedure for candidate countries and in accordance with existing European standards. And the possibility of Ukraine's membership in the European Union should become strategic direction of modernization transformations in the state aimed at building a democratic welfare state with a strong economy and a developed civil society.
\end{abstract}

Keywords: European integration, state policy in the sphere of European integration, Association Agreement between Ukraine and the European Union.

Постановка проблеми. Орієнтиром розвитку України в сучасних умовах $\epsilon$ країни-члени Європейського Союзу, які мають ефективнішу систему державного управління, де громадяни є більш захищеними у своїх правах, мають вищий рівень життя та впевненість у майбутньому. Шлях до 
цього орієнтиру пролягає для України через процес європейської інтеграції внутрішні реформи, викорінення корупції, адаптацію до європейських стандартів, економічну інтеграцію та політичну асоціацію з ЄС. Тому актуальними $\epsilon$ питання формування та реалізації нової державної політики у сфері європейської інтеграції, яка відповідає існуючим викликам сьогодення.

Аналіз останніх досліджень і публікацій. Розгляду особливостей формування та реалізації державної політики у сфері європейської інтеграції України присвятили свої публікації такі дослідники, як Емерсон М., Пашков М., Шульга Д., Якименко Ю. та ін. Однак чимало питань стосовно напрямів трансформації державної політики у сфері європейської інтеграції України в сучасних умовах залишаються недостатньо дослідженими.

Метою статті $\epsilon$ визначення напрямів трансформації державної політики у сфері європейської інтеграції України в умовах глобальних викликів.

Виклад основного матеріалу. Динаміку ставлення громадян України до Європейського Союзу та специфіку процесів європейської самоіндентифікації населення нашої країни можна проаналізувати за результатами соціологічних опитувань Центру Разумкова [1], згідно з якими кількість прихильників євроінтеграції постійно переважала над іiі противниками.

На ставлення громадян України до різних векторів інтеграції європейської чи євразійської, вплинули Революція гідности у грудні 2013 січні 2014 рр., яка відстояла європейський курс розвитку України, а також російська агресія, яка фактично зняла з порядку денного євразійський вектор інтеграції для України. Якщо протягом довоєнних років (2011-2013рр.) частка прихильників євразійської інтеграції складала близько третини респондентів, то в подальші роки частка симпатиків Євразійського економічного союзу (колишнього Митного союзу країн СНД) знизилась - у 2015 р. до 15,9\%, а в 2017 р. - до 7,8\%. Відповідно зросла частка прихильників євроінтеграційного шляху.

Сьогодняшній рівень i характер проєвропейських симпатій українського суспільства відмічається якісно новим характером мотивації. Громадяни, з одного боку, вже більш реально усвідомлюють складнощі і тривалість євроінтеграції, а з іншого усвідомлюють природність для України саме європейського шляху, й у т.ч. як засобу збереження національної державності у протистоянні агресивному російському впливу.

Отже, частка громадян, які тією чи іншою мірою відчувають себе європейцями, відчувають свою належність до культури та історії європейського співтовариства у 2017 р. порівняно з 2009 р. зросла з 31,4\% до $40,3 \%$. Водночас, частка респондентів, які не ототожнюють себе з Європою зменшилася $363,4 \%$ до 50,4\%. Наведена динаміка виглядатиме досить оптимістично на фоні часового масштабу формування загальноєвропейської ідентичності в рамках ЄС.

Досить показовою ілюстрацією рівня проєвропейських настроїв в українському суспільстві $є$ потенційна готовність громадян голосувати на 
гіпотетичному референдумі за вступ України до ЄС. 32014 р. спостерігається тенденція зростання європейських симпатій в суспільстві: в грудні 2017 p. вже майже $60 \%$ українських громадян підтримували вступ України до ЄС. [1].

Однак в подальшому можна спостерігати тенденцію до сталості i, навіть, деякого зниження показника підтримки євроінтеграції серед населення України.

Так, наприклад, в опитуванні, проведеному групою Рейтинг з 30 квітня по 10 травня 2019 р., вступ України в СС підтримували 57\%, що нижче за показник грудня 2017 р. I це при тому, що Україна потрапила в число країн, чиє населення в переважній більшості позитивно ставиться до Євросоюзу (такі результати показало опитування людей в 33 країнах, проведене американським дослідницьким центром Pew, яке показало, що 79\% українців позитивно ставляться до Євросоюзу, а вище ці показники тільки у двох країн - членів СС: Польщі (84\%) і Литви (83\%) та Південній Кореї - 80\% [2]).

Деяке зниження показника підтримки євроінтеграції серед населення України в останні роки може свідчити про зниження ефективності та результативності державної політики у сфері європейської інтеграції, яка потребує трансформації у відповідних напрямах іiі реалізації в сучасних умовах глобальних викликів для України.

Ефективність та результативність державної політики у сфері європейської інтеграції України значною мірою залежить від вчасного виконання нашою державою Угоди про асоціацію з СС (далі - УА), яку в частині секторальної інтеграції Україна має завершити не пізніше кінця 2023 p., а загалом всі положення Угодимають бути виконані не пізніше 31 грудня 2025 p. [3].

За результатами виконання УА, 28 січня 2020 р. в Брюсселі пройшло вже Шосте засідання Ради асоціації Україна - Свропейський Союз (спільне засідання українського Уряду та Європейської Комісії), на якому сторони обговорили низку важливих питань та ухвалили спільну заяву, у якій $\mathrm{CC}$ відзначив суттєвий прогрес реформ в Україні.

Окрему увагу в контексті виконання УА приділено співпраці у сфері охорони навколишнього природного середовища та боротьбі з наслідками змін клімату. Зокрема, сторони домовилися про подальші кроки задля захисту довкілля та зниження рівнів викидів вуглецю у рамках Європейської зеленої угоди та погодилися надалі спільно впроваджувати амбітну політику із захисту довкілля, зокрема, для виконання зобов'язань за Паризькою кліматичною угодою.

Рада асоціації звертає увагу на важливість залучення регіонів України до євроінтеграції та ініціативу Уряду 3 відкриття регіональних офісів євроінтеграції, які сприятимуть зв'язкам українських регіонів з СС. Сторони також підтвердили спільний намір продовжити роботу над відкриттям курсів Коледжу Свропи для українських державних службовців.

У тексті заяви сторони також підтримали зацікавленість України 
розширити участь у програмах $\mathrm{CC}$, зокрема таких як «Креативна Свропа» та «Горизонт Європа» i відзначили необхідність прискорення адаптації законодавства України у сфері транспорту і важливість якнайшвидшого укладення Угоди про спільний авіаційний простір.

Рада асоціації підкреслила важливість медіа плюралізму, збереження свободи вираження поглядів і ЗМІ та привітала вирішальну роль, яку громадянське суспільство продовжує відігравати у цій сфері, погодившись 3 необхідністю швидкого та ретельного розслідування нападів на громадських активістів та журналістів. При цьому наголошується, що реформа Служби безпеки України та посилення демократичного нагляду за сектором безпеки залишаються ключовими.

В цілому, Свропейський Союз підтвердив непохитну підтримку незалежності, суверенітету та територіальної цілісності України в межах ії міжнародно визнаних кордонів, позитивно відзначив зусилля України 3 мирного врегулювання на Донбасі i рішуче засудив порушення територіальної цілісності та суверенітету України, яке розпочалося актами агресії збройних сил Росії з лютого 2014 р. [4].

Отже, Україна має послідовно виконувати своє «домашнє завдання», адже дедалі більше поставатиме питання про прийняття рішень $Є \mathrm{C}$ про інтеграцію України до внутрішнього ринку СС у відповідних секторах, як це передбачено Угодою про асоціацію між сторонами.

Так, у 2020 р. Україна має забезпечити прогрес у секторальній інтеграції у рамках УА [5]:

укладення угоди АСАA;

визнання еквівалентності систем санітарного та фітосанітарного захисту у ключових секторах сільськогосподарських товарів;

визнання авторизованих економічних операторів;

приєднання України до єдиної транзитної системи ЄС (NCTS);

оновлення Додатку XVII-3 та укладення угоди про взаємне визнання електронних довірчих послуг між Україною та СС;

рішення органів асоціації про доступ до ринку державних закупівель на рівні завершеного третього етапу Індикативного плану;

підписання угоди про спільний авіаційний простір.

До позитивних змін в контексті євроінтеграційних прагнень України, можна відзначити той факт, що завдяки останнім законодавчим новаціям Урядовий офіс координації європейської та євроатлантичної інтеграції та профільний Віце-прем'єр-міністр у жовтні 2019 р. отримали право подавати власні проєкти актів на розгляд Кабінету Міністрів України [6].

Однак, окрім цього, необхідно посилити повноваження Урядового офісу координації європейської та євроатлантичної інтеграції щодо аналізу та контролю нормативно-правових актів, які виносяться на розгляд Уряду.

Також доцільно зберегти відповідний профільний комітет у Верховній раді та посади заступників профільних міністрів 3 питань євроінтеграції 
(нажаль, $\epsilon$ намагання їх скасувати), оскільки вони $є$ складовою координаційного механізму державного управління у сфері євроінтеграції та сприяють виконанню УА. Взагалі, на наш погляд, доречним є створення окремого міністерства, відповідального за весь напрямок європейської інтеграції України.

Окрім того, вважаємо, що має змінитися політика «Східного партнерства» Свропейського Союзу до країн, які активно прагнуть євроінтеграції. Так, три Угоди про асоціацію ЄС 3 Грузією, Молдовою та Україною, стали найбільшим досягненням СС в рамках ширшого Східного партнерства. Саме ці три країни (в тому числі Україна), на відміну від Білорусі чи Азербайджану, а також частково Вірменіі, серйозно налаштовані на економічну та політичну інтеграцію 3 СС в рамках зазначеного партнерства.

Тим більше, що в 2019 р. Сврокомісія ініціювала відкриту «структурну консультацію» із зацікавленими сторонами щодо майбутнього Східного партнерства шляхом поглиблення процесу інтеграції у форматі цих Угод про асоціацію через запровадження «тристоронізації» відносин 3 СС, тобто колективного обговорення всіх питань, що становлять спільний інтерес, налагодження процесу спільних зустрічей $\mathrm{CC}$ та зазначених країн на міністерському та експертному рівнях. Наприклад, сторони можуть започаткувати спільну «Раду асоціації СС та трьох країн УА», а також різні формати для зустрічей із галузевими радами $\mathrm{CC}$ або робочими групами Ради EC, такими, як COEST (Робоча група EC 3 питань Східної Свропи та Центральної Азії).

Усе це має бути націлено на пошук широких грунтовних ініціатив через застосування двох концептів: «оновлення» та «модернізація» Угоди про асоціацію з СС.

Так, оновлення Додатків до текстів УА згідно 3 переглянутим законодавством СС - це процес, передбачений угодами, який триває на практиці. 3 моменту укладання угод законодавство $Є С$ було суттєво оновлено у багатьох галузях політик, i тому угоди потребують великої кількості суто технічного оновлення, що наразі і відбувається.

Окрім того, є можливість для якісного поглиблення зазначених угод, тобто їх «модернізації». Так, Україна, Грузія та Молдова висунули чимало відповідних пропозицій, які можуть слугувати поступовими практичними кроками з модернізації угод, а саме: більш повна інтеграція в енергетичний союз, єдиний цифровий ринок, транспортну політику та інфраструктурні зв'язки, єдину європейську мережу розрахунків, ініціативи у сфері правосуддя, нові зміни в кібербезпеці тощо.

Ці можливості могли б посприяти новому важливому політичному поштовху, якого прагнуть зазначені країни і це цілком відповідає гаслу «більше підтримки за більше реформ» («More for more»), яке $С С$ вже протягом певного часу використовує у своїх заявах щодо політики сусідства. 3 іншого боку, це додаткові можливості для забезпечення необхідного рівня зовнішньої та безпекової політики в різних сферах [7]. 
Таким прикладом може служити спеціальна програма допомоги країнам-учасницям «Східного партнерства» в боротьбі з наслідками пандемії коронавірусной хвороби «V4EastSolidarity program» в рамках діяльності Міжнародного вишеградського фонду країн «Вишеградської групи» [8].

Коли порівнюють українські євроінтеграційні реформи 3 реформами, які пройшли раніше країни Східної Свропи, часто наголошуються, що ці країни мали перевагу, адже у них була перспектива членства СС, чого наразі позбавлена Україна. I хоча багато східноєвропейських країн мали перевагу у вигляді перспективи членства в СС, однак водночас це не виправдовує того факту, що Україна далеко не завжди впроваджує дієві та результативні реформи, необхідні для успішного подолання євроінтеграційного шляху. В той же час, у нашої країни, щоб повторити євроінтеграційний шлях успіху інших країн, є все необхідне, в тому числі Угода про асоціацію, яку потрібно ефективно використовувати шляхом відповідної трансформації державної політики у сфері європейської інтеграції.

Так, Угода про асоціацію між Україною та ЄС є угодою про «політичну асоціацію та економічну інтеграцію». У той час, як «економічна інтеграція»є усталеним терміном, термін «політична асоціація» не має жодного пояснення у тексті Угоди, відсутній в системі права СС і не достатньо досліджений науковцями.

Тобто ті питання, які Європейський Союз у політичному діалозі 3 Україною визначає як пріоритетні, недостатньо врегульовані в УА. Тому відповідні статті Розділу II «Політичний діалог та реформи, політична асоціація, співробітництво та конвергенція у сфері зовнішньої та безпекової політики» та Розділу III «Юстиція, свобода та безпека» УА містять лише загальні формулювання.

Разом 3 тим, низка політичних принципів визначена у тексті УА, як їі «основні елементи», а саме:

повага до демократичних принципів, прав людини та основоположних свобод;

повага до принципу верховенства права;

повага до принципів суверенітету й територіальної цілісності, непорушності кордонів і незалежності;

протидія розповсюдженню зброї масового знищення, пов'язаних 3 нею матеріалів та засобів їхньої доставки.

Більше того, ці «політичні» положення УА практично відповідають формулюванню першого - політичного - Копенгагенського критерію членства у СС: «Стабільність інституцій, що гарантують демократію, верховенство права, права людини та повагу та захист меншин» [9].

Тобто, виконання політичної частини УА («політичної асоціації»), вочевидь, наблизить Україну до відповідності першому критерію членства у $\mathrm{EC}$, виконання якого необхідне перед початком переговорів про вступ в 
Євроспільноту.

В цьому контексті слід зазначити, що у лютому 2020 р. Свропейська комісія прийняла нові правила розширення $\mathrm{CC}$, які передбачають більшу вагу держав-членів у переговорах 3 кандидатами про вступ до цього співтовариства.

Так, Європейська комісія пропонує державам-членам ЄС вносити більш систематичний внесок у процес вступу, в тому числі за допомогою моніторингу на місцях через своїх експертів, шляхом безпосередньої участі в щорічних звітах і за допомогою галузевої експертизи. У держав-членів також буде більше можливостей регулярно переглядати і контролювати загальний прогрес.

Документ передбачає створення додаткових стимулів для країнпретендентів, які показують позитивні результати. Серед них - збільшення фінансування, якщо країни показують прогрес у реформах, i тісніша співпраця 3 міжнародними фінансовими інститутами для посилення підтримки. Якщо ж країни демонструватимуть відкат чи затримку в проведенні необхідних реформ, це може призвести до санкцій - наприклад, припинення фінансування або переговорів про вступ. Також документ передбачає можливість нового відкриття вже закритих глав у переговорах. Обсяг та інтенсивність фінансування СС можуть бути скориговані в бік зниження (виняток - підтримка громадянського суспільства). Водночас вигоди від тіснішої інтеграції, наприклад, доступ до програм ЄС чи односторонні поступки в доступу до ринків можуть бути скасовані.

Нова методологія вступу в ЄС буде застосовуватися до Албанії, Боснії і Герцеговині, Косова і Північної Македонії. Адже ці нові правила були розроблені після того, як ЄС у жовтні 2019 р. вкотре відмовився починати переговори щодо вступу з Північною Македонією та Албанією, адже ці країни не показали достатнього прогресу в проведенні реформ, не достатньо боролися 3 корупцією та надто слабко працювали над зміцненням верховенства права [10].

Слід зазначити, що рушійної силою зміни правил розширення ЄС стала Франція. А ключовою у реформованому підході до процесу приєднання до ЄС стала ідея «поступової асоціації».

Раніше розширення СС відбувалося шляхом відкриття переговорів про приєднання із країнами-кандидатами, які охоплюють 35 окремих сфер європейського права і після того, як кандидати погоджувалися здійснити необхідні реформи, їх приймали, як повноправних членів співтовариства.

Зараз, в новій французькій моделі вступ буде семикроковим процесом, впродовж якого кандидати отримуватимуть доступ до обраних програм та фондів $Є С$, перш ніж прийти до повноправного членства.

Сім кроків - це: (I) верховенство права та основні права; (II) освіта та наука; (III) зайнятість та соціальні справи; (IV) фінансові справи; V) єдиний ринок, сільське господарство та рибальство; (VI) закордонні справи; (VII) та - інші. 
Якщо країни-кандидати завершили перший крок, вони можуть, наприклад, вступати до Євроюсту. На другому етапі країни можуть отримати доступ до наукової програми «Горизонт 2020», на третьому - брати участь у програмі обміну студентами Erasmus + . Крок четвертий може забезпечити приєднання до банківського союзу СС, а крок п'ятий - наділить країникандидати правами на структурні фонди - багатомільярдні субсидії. Завершення переговорів, відповідне кожному кроку, здійсненому країною, відкриває можливість участі у відповідних програмах $Є С$, бути пов'язаним 3 певною відповідною галузевою політикою та отримати певне цільове фінансування. Кінцевою метою залишається повне та цілковите приєднання країни до ЄС [11].

Отже, Європейський Союз змінює правила приєднання країн, які дещо ускладнюють цю процедуру. Нові правила мають велике значення і для України, адже якщо країна робить крок назад у реформах чи зупиняє їх, СC може не просто призупинити переговори, а розпочати все спочатку або знову повернутися до тих глав, які вже були закриті. Водночас, за новими правилами країна, яка результативно працює, має шанс завершити переговори про приєднання навіть швидше, аніж це відбувалося за правилами вступу, які діяли раніше.

Тобто Європейський Союз не закриває двері для вступу нових країнчленів із впровадженням нової процедури, і та країна, яка насправді бажає та наполегливо працює отримує відповідні можливості, хоча шлях стає дещо складнішим, що потрібно враховувати Україні при формуванні та реалізації державної євроінтеграційної політики в середньостроковій перспективі.

I лише від України значною мірою залежить, коли саме вона зможе стати повноправним членом Свропейського Союзу, тим більше, що у цьому питанні у нашої країни є чимала підтримка від населення країн ЄС.

Так, як свідчать результати соцопитування, проведеного у 2019 р., 48\% мешканців Німеччини, Франції, Великої Британії, Італії, Нідерландів, Польщі та Литви підтримують вступ України до Свросоюзу, а переважна більшість (79\%) вважають, що Україна стане членом СС в найближчому майбутньому [12].

Висновки та перспективи подальших досліджень. В сучасних умовах державна політика у сфері європейської інтеграції України має зазнати певної трансформації, яка передбачає відповідну зміну вектору вирішення політичних, правових, економічних, соціальних, екологічних, гуманітарних питань 3 урахуванням змін у процедурі вступу для країнпретендентів та у відповідності з існуючими європейськими стандартами. А можливість членства України в Європейському Союзі має стати стратегічним напрямом модернізаційних перетворень в державі, спрямованих на побудову демократичної соціальної держави 3 міцною економікою та розвинутим громадянським суспільством, що й буде предметом подальших наукових досліджень.

\section{Лimepamypa:}


1. Якименко Ю., Пашков М. Україна на шляху до СС: оцінки, думки і сподівання громадян. / Центр Разумкова. URL: http://razumkov.org.ua/statti/ukraina-na-shliakhu-do-yesotsinky-dumky-i-spodivannia-hromadian (дата звернення: 20.05.2020).

2. Україна виявилася найдоброзичливішою до Євросоюзу країною. / UA.NEWS URL : https://ua.news/ua/ukrayna-okazalas-samoj-blagozhelatelnoj-k-evrosoyuzu-stranoj/ (дата звернення: 20.05.2020).

3. Шульга Д. Євроінтеграція-2020: що має стати пріоритетом у виконанні Угоди з EC. / вебпортал Свроінтеграція.URL: https:/www.eurointegration. com.ua/articles/2020/01/13/7104931/ (дата звернення: 20.05.2020).

4. Рада асоціації Україна-СС високо оцінила плани українського Уряду та результати на шляху інтеграції України з Свросоюзом: спільна заява. / Урядовий портал. URL: $\quad$ https://www.kmu.gov.ua/news/rada-asociaciyi-ukrayina-yes-visoko-ocinila-planiukrayinskogo-uryadu-ta-rezultati-na-shlyahu-integraciyi-ukrayini-z-yevrosoyuzom-spilnazayava (дата звернення: 20.05.2020).

5. Україна домовилися з СС про оновлення Угоди про асоціацію. / Інтернет видання Epravda. URL: https://www.epravda.com.ua/news/2020/01/28/656384/ (дата звернення: 20.05.2020).

6. Віце-прем’єр-міністр з європейської та євроатлантичної інтеграції отримав право подавати власні законопроекти на розгляд Кабміну. / Урядовий портал. URL : https://www.kmu.gov.ua/catalog/ministerstvo-cifrovoyi-transformaciyi (дата звернення: 20.05.2020).

7. Емерсон М. Виграшний хід $\mathrm{CC}$ : як має змінитися політика щодо Східного партнерства / вебсайт євроінтеграція. URL: https://www.eurointegration.com.ua/experts/2019/12/16/7104071/ (дата звернення: 20.05.2020).

8. Кулеба Д. Украина готова к усилению экономической интеграции с ЕС. / Інтернетвидання цензор. URL : https://biz.censor.net.ua/news/ 3187979/ukraina_gotova_k_usileniyu_ ekonomicheskoyi_integratsii _s_es_ kuleba (дата звернення: 20.05.2020).

9. Шульга Д. Євроінтеграція-2020: що має стати пріоритетом у виконанні Угоди 3 €C. / Вебсайт євроінтеграція. URL : https://www.eurointegration. com.ua/articles/2020/01/13/7104931/ (дата звернення: 20.05.2020).

10. Єврокомісія на вимогу Франції підготувала нові правила розширення ЄС. / вебсайт євроінтеграція. / Вебсайт євроінтеграція. URL: https:/www.eurointegration.com.ua/news/ 2020/ 02/5/7105990/ (дата звернення: 20.05.2020).

11. Франція оприлюднила нову модель розширення $\mathrm{CC.} \mathrm{/} \mathrm{Вебсайт}$ євроінтеграція.URL: https://www.eurointegration.com.ua/news/2019/11/19/7103215/ (дата звернення: 20.05.2020).

12. Україна в СC: Німеччина різко міняє курс. / Інтернт видання znaj.ua.URL: https://znaj.ua/politics/ukrayina-v-yes-nimechchyna-rizko-minyaye-kurs. (дата звернення: 20.05.2020).

\section{References:}

1. Yakymenko, Y. \& Pashkov, M. Ukrayina na shlyakhu do YES: otsinky, dumky i spodivannya hromadyan. [Ukraine on the way to the EU: assessments, thoughts and hopes of citizens]. (n.d.). razumkov.org.ua. Retrieved from: http://razumkov.org.ua/statti/ukraina-nashliakhu-do-yes-otsinky-dumky-i-spodivannia-hromadian. [in Ukrainian].

2. Ukrayina vyyavylasya naydobrozychlyvishoyu do Yevrosoyuzu krayinoyu. [Ukraine turned out to be the most friendly country to the European Union]. (n.d.). ua.news. Retrieved from: https://ua.news/ua/ukrayna-okazalas-samoj-blagozhelatelnoj-k-evrosoyuzu-stranoj/. [in Ukrainian].

3. Shul'ha, D. Yevrointehratsiya-2020: shcho maye staty priorytetom u vykonanni Uhody 
z YES. [European integration-2020: what should become a priority in the implementation of the Agreement with the EU]. (n.d.). eurointegration.com.ua. Retrieved from: https://www.eurointegration.com.ua/articles/2020/01/13/7104931/. [in Ukrainian].

4. Rada asotsiatsiyi Ukrayina-YES vysoko otsinyla plany ukrayins'koho Uryadu ta rezul'taty na shlyakhu intehratsiyi Ukrayiny z Yevrosoyuzom: spil'na zayava. [he EU-Ukraine Association Council praised the plans of the Ukrainian Government and the results on the path of Ukraine's integration with the European Union: a joint statement]. (n.d.). kmu.gov.ua. Retrieved from: $\quad$ https://www.kmu.gov.ua/news/rada-asociaciyi-ukrayina-yes-visoko-ocinila-planiukrayinskogo-uryadu-ta-rezultati-na-shlyahu-integraciyi-ukrayini-z-yevrosoyuzom-spilnazayava. [in Ukrainian].

5. Ukrayina domovylysya z YES pro onovlennya Uhody pro asotsiatsiyu. [Ukraine has agreed with the EU to renew the Association Agreement]. (n.d.). epravda.com.ua. Retrieved from: https://www.epravda.com.ua/news/2020/01/28/656384/. [in Ukrainian].

6. Vitse-prem"yer-ministr z yevropeys'koyi ta yevroatlantychnoyi intehratsiyi otrymav pravo podavaty vlasni zakonoproekty na roz hlyad Kabminu. [The Deputy Prime Minister for European and Euro-Atlantic Integration has the right to submit his own bills to the Cabinet of Ministers]. (n.d.). kmu.gov.ua. Retrieved from: https://www.kmu.gov.ua/catalog/ministerstvocifrovoyi-transformaciyi. [in Ukrainian].

7. Emerson, M. Vyhrashnyy khid YES: yak maye zminytysya polityka shchodo Skhidnoho partnerstva. [Winning move of the EU: how to change the policy of the Eastern Partnership]. (n.d.). eurointegration.com.ua. Retrieved from: https://www.eurointegration.com.ua/experts/2019/12/16/ 7104071/. [in Ukrainian].

8. Kuleba, D. Ukraina gotova k usileniyu ekonomicheskoy integratsii s YES. [Ukraine is ready to strengthen economic integration with the EU]. (n.d.). biz.censor.net.ua. Retrieved from: https://biz.censor.net.ua/news/3187979/ukraina_gotova_k_usileniyu_ekonomicheskoyi_integrats ii_s_es_kuleba. [in Russian].

9. Shul'ha, D. Yevrointehratsiya-2020: shcho maye staty priorytetom u vykonanni Uhody z YES. [European integration-2020: what should become a priority in the implementation of the Agreement with the EU]. (n.d.). eurointegration.com.ua. Retrieved from: https://www.eurointegration.com.ua/articles/2020/01/13/7104931/. [in Ukrainian].

10. Yevrokomisiya na vymohu Frantsiyi pidhotuvala novi pravyla rozshyrennya YES. [At the request of France, the European Commission has prepared new rules for EU enlargement]. (n.d.). eurointegration.com.ua. Retrieved from: https://www.eurointegration.com.ua/news/2020/02/5/ 7105990/. [in Ukrainian].

11. Frantsiya oprylyudnyla novu model' rozshyrennya YES. [France has unveiled a new model for EU enlargement]. (n.d.). eurointegration.com.ua. Retrieved from: https://www.eurointegration.com.ua/news/2019/11/19/7103215/. [in Ukrainian].

12. Ukrayina v YES: Nimechchyna rizko minyaye kurs. [Ukraine in the EU: Germany is changing course dramatically]. (n.d.). znaj.ua. Retrieved from: https://znaj.ua/politics/ukrayinav-yes-nimechchyna-rizko-minyaye-kurs. [in Ukrainian]. 